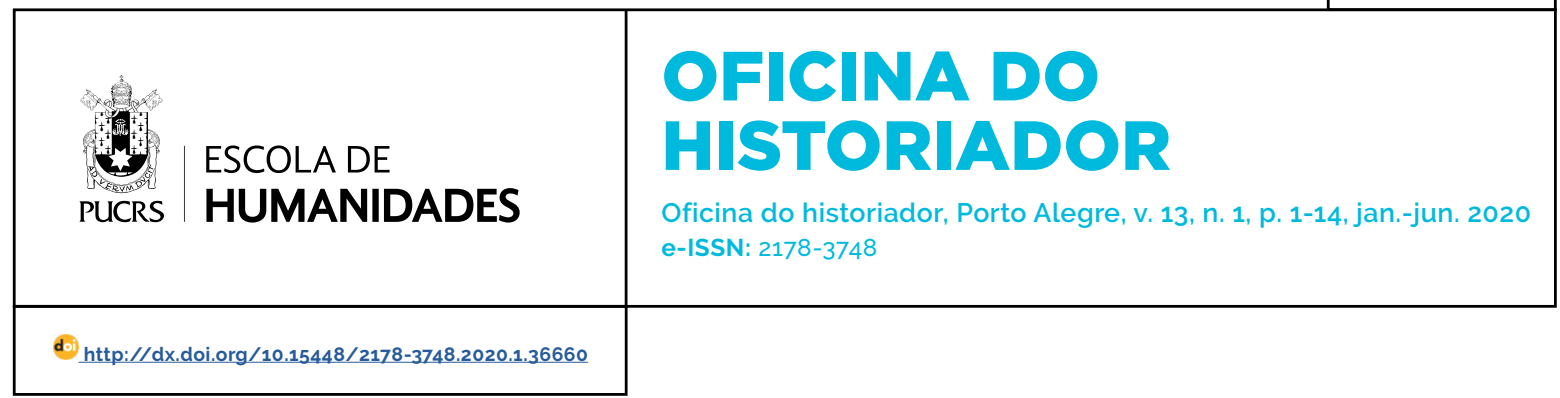

SEÇÃO: ARTIGOS

\title{
"Êste é o Humberto" - Estratégias de construção simbólica da revista Realidade no perfil do primeiro líder da ditadura civil-militar
}

\author{
"Éste é o Humberto" - Strategies of symbolic construction of the Realidade \\ magazine on the profile of the first leader of the civil-military dictatorship
}

\author{
Jonas Migotto Filho ${ }^{1}$ \\ orcid.org/0000-0001-9325-6336 \\ migottojonas@gmail.com
}

Recebido em: 15 dez. 2019

Aprovado em: 27 jan. 2020

Publicado em: 14 jun. 2020.

\section{(c) (1)}

Artigo está licenciado sob forma de uma licença Creative Commons Atribuição 4.0 Internacional.
Resumo: Realidade foi uma revista publicada pela editora Abril entre os anos de 1966 e 1976, durante a ditadura civil-militar brasileira. Em algumas edições, o repórter Luiz Fernando Mercadante publicou uma série de perfis dos líderes do governo ditatorial, um aspecto conservador em uma revista majoritariamente transgressora, principalmente quando pautava o plano dos costumes. Neste artigo, será realizada uma análise do perfil de Humberto de Alencar Castelo Branco, intitulado "Êste é o Humberto", publicado na edição número 3, de junho de 1966. Para isso, a narrativa é entendida como produtora de formas simbólicas a fim de sustentar relações de dominação e, na análise, também são levados em consideração os aspectos contextuais e iconográficos.

Palavras-chave: Revista Realidade. Ditadura Civil-Militar. Humberto de Alencar Castelo Branco.

Abstract: Realidade was a magazine published by Abril between 1966 and 1976 , during the Brazilian civil-military dictatorship. In some editions, the reporter Luiz Fernando Mercadante published a series of profiles of dictatorial government leaders, a conservative aspect in a mostly transgressive magazine, especially when especially when the customs plan was on the agenda. In this article, will be performed an analysis of the profile of Humberto de Alencar Castelo Branco, entitled "Êste é o Humberto", published in issue number 3. June 1966. For this, the narrative is understood as the producer of symbolic forms in order to sustain relations of domination and, in the analysis, also taking into account the contextual and iconographic aspects.

Keywords: Realidade magazine. Civil-military dictatorship. Humberto de Alencar Castelo Branco.

\section{Introdução}

A revista Realidade foi uma publicação da editora Abril, lançada no ano de 1966. Ela foi idealizada majoritariamente pelo jornalista Paulo Patarra, redator-chefe nos primeiros anos, atendendo a uma vontade da editora de entrar no nicho de Interesse Geral. Patarra também foi responsável pela montagem da primeira equipe de repórteres. Logo, Realidade tornouse a maior revista do País em circulação, alcançando a marca recorde de 505.300 exemplares nas bancas na edição 11 de fevereiro de 1967. A 
história de Realidade costuma ser dividida em três fases (LEISTER FILHO, 2003). Na primeira fase, de abril de 1966 até dezembro de 1968, observa-se o periodo de maior sucesso, com maior liberdade nas pautas e um número crescente de vendas. As reportagens desse período são consideradas um marco na imprensa brasileira, pela forma de abordagem dos costumes, questionando os padrões morais da época e pela qualidade de texto, em estilo jornalismo literário.

Em dezembro de 1968, a capa de Realidade trazia o rosto de Luís Carlos Prestes com a manchete: "Êste rosto não existe mais"3. Essa seria a última contribuição de Paulo Patarra para a revista. Na função de repórter, ele narra as dificuldades para conseguir um encontro com Prestes e a conversa que tiveram. Nessa edição, seu nome já não aparece no expediente. O cargo havia sido passado ao jornalista Milton Coelho, o que foi veementemente desaprovado pelo restante da equipe (SEVERIANO, 2013). O fato acarretou um pedido de demissão em massa da equipe originária. Não bastassem as perdas irreparáveis, o contexto também já não era o mesmo. O Ato Institucional $n^{\circ} 5$ seria decretado logo em seguida pelo ditador Artur da Costa e Silva. Se antes Realidade gozava de certa liberdade na escolha dos temas, mas operava sob a cautela da autocensura (MARÃO; RIBEIRO, 2010), agora a censura estava institucionalizada e a repressão se intensificava no Brasil, comprometendo seriamente a liberdade de imprensa. Isso exigiria um cuidado muito maior por parte da equipe. Inevitavelmente, as limitações para o desenvolvimento dos trabalhos se agravariam. A equipe se dissipou. Alguns foram para a imprensa alternativa, outros partiram para a luta armada para combater o governo ditatorial. Começou a chamada segunda fase da revista.

Nessa segunda fase, de 1969 até 1973, a revista buscou alternativas de sobrevivência para manter o padrão com que os leitores estavam acostumados. Alguns dos repórteres da primeira fase que haviam saído, como José Hamilton Ribeiro, José Carlos Marão, Luiz Fernando Mercadante e Roberto Freire, retornaram para a revista. A publicação até conseguiu bons indices de vendas, principalmente quando apostou nas edições temáticas. Em meio ao clima acentuado de repressão e às tentativas de recuperar o prestígio e o sucesso, muitas reportagens de qualidade foram produzidas. O período não foi completamente inexpressivo em relação à qualidade de produção, mas as edições e a equipe, mesmo entre os que retornaram, não possuíam o mesmo brilho e ímpeto de outrora.

Na terceira fase, iniciada em outubro 1973. a revista passou por uma mudança radical, perdendo suas características fundamentais, até deixar de existir. Nessa nova fase, o objetivo da editora era aproximar o estilo da revista com Seleções do Reader's Digest, publicação de origem norte-americana que teve sucesso nas décadas de 1940 e 1950 com sua versão brasileira (LEISTER FILHO, 2003). Dessa forma, Realidade aumentou o número de seções fixas, os textos se tornaram mais curtos e fez uso de uma fórmula colaborativa: comprar alguns textos enviados pelos leitores, embora ainda produzisse reportagens próprias. Realidade estava completamente descaracterizada, se colocada ao lado das edições dos primeiros anos, que consagraram a publicação.

Em seus primeiros anos, Realidade adotou uma prática recorrente para amenizar as polêmicas presentes nas páginas da revista: escrever perfis ${ }^{4}$ dos líderes do governo ditatorial e de outras figuras ligadas ao poder. Todos esses perfis foram escritos pelo jornalista Luiz Fernando Mercadante. Neste artigo, será realizada uma análise do perfil "Êste é o Humberto", presente na edição número 3. de junho de 1966, sobre o primeiro militar lider da ditadura, Humberto de Alencar Castelo Branco. Com base em Thompson (2011), busca-se analisar as formas simbólicas construídas por Realidade para seus leitores e como o sentido produzido

Durante o artigo, a ortografia da época foi mantida em todas as citações da revista

4 "Diferentemente das biografias em livro, em que os autores têm de enfrentar os pormenores da história do biografado, os perfis podem focalizar apenas alguns momentos da vida da pessoa. É uma narrativa curta tanto na extensão (tamanho do texto) quanto no tempo de validade de algumas informações e interpretações do repórter" (VILAS BOAS, 2003, p. 13). 
servia para sustentar relações de dominação, adquirindo, assim, um caráter ideológico. A análise também alia as concepções de Motta (2013) acerca da análise crítica da narrativa, fornecendo ferramentas a fim de refinar o olhar para o texto e compreender suas estruturações e produções de sentido na construção do personagem perfilado.

\section{O aspecto conservador de Realidade e as estratégias de construção simbólica}

Por se tratar de uma revista mensal de reportagens de interesse geral, Realidade contou com uma ampla variedade temática em suas pautas. Faro (1999) mostra que as visões dos diferentes temas apresentados em Realidade podem ser vistas sob dois aspectos:

O primeiro, é a transgressão lgrifos do autorl dos elementos consensuais que cercavam convencional ou oficialmente os assuntos que Realidade reportou. A publicação da Abril assumia mesmo, perante seu corpo de jornalistas e perante seu público leitor, a imagem de um órgão para o qual não havia tabus, no sentido de que se dispunha a avançar sobre o que não se discutia ou sobre assuntos a respeito dos quais se discutia timidamente. Como se pretende demonstrar. a revista investigou e desnudou todo o universo simbólico conservador que povoava a moral cotidiana das classes médias urbanas brasileiras, ou acompanhou as transformações que esse universo apresentava. Nesse sentido, Realidade trazia à tona o questionamento de padrões que já ocorria surdamente no processo de modernização e de crescente autoritarismo da vida brasileira. Em decorrência disso, a revista polemizou com tais valores permanentemente, transgrediu portanto a convenção estabelecida e acabou se contrapondo ao discurso ético-político através do qual o Estado buscava legitimar sua existência (FARO, 1999, p. 107, grifo do autor).

Se a transgressão é o primeiro aspecto, a conservação - o polo oposto - é a segunda forma pela qual Realidade pode ser compreendida5.
Pelo menos até o fim de 1968, esse aspecto não representava um padrão dominante na revista. Entretanto, ele podia ser percebido nas páginas da publicação, principalmente nos perfis ligados ao governo ditatorial do período. Faro (1999) insere a publicação desses perfis dentro de uma dinâmica de negociação com o Estado autoritário. Severiano (2013) também evidencia o caráter político e intencional do espelho da revista, ou seja, da disposição das matérias. Dessa forma, a revista "mordia e assoprava" para que as criticas sutis ou as polêmicas pudessem ser digeridas pelos militares. Os textos que humanizavam os líderes da ditadura podem ser lidos como forma de minimizar as polêmicas inseridas nas demais páginas das edições.

Castelo Branco foi retratado em "Êste é o Humberto", na edição número 3, objeto de análise deste artigo. Costa e Silva ganhou as páginas da revista em "Feliz aniversário seu Artur" no número 2, quando ainda era Ministro da Guerra e, depois, em "Um garôto chamado Artur", no número 11, e "Há um nôvo tempêro no poder", no número 15. A esposa do general também teve seu perfil publicado em "Dona Yolanda, a presidenta", no número 13. Além disso, Médici, já na segunda fase da revista, foi perfilado em "Êste é o presidente", edição 57, de dezembro de 1970. Essas matérias sempre eram escritas por Luiz Fernando Mercadante, uma espécie de elo diplomático de bom trânsito com a direita dentro da equipe de repórteres. Marão e Ribeiro (2010, p. 29) mostram que esses perfis eram uma forma de contrabalançar possiveis provocações, mas, além disso, "havia um interesse legítimo dos leitores em saber quem e como eram aqueles militares desconhecidos fora do seu meio que, de repente, estavam mandando".

Neste artigo, entenderemos o aspecto da conservação como formas simbólicas ${ }^{6}$ ideológicas com a finalidade de estabelecer e sustentar relações de dominação (THOMPSON, 2011). A

\footnotetext{
5 Faro (1999, p. 108) ressalta que a revista não se esgotava apenas nesses dois aspectos. "Havia matérias e seções de outra natureza em segundo plano: crítica musical, crítica teatral, crítica literária, comentários curtos sobre transformações na mídia". O autor observa esse outro conjunto como um referencial para a conjuntura cultural da época representado por Realidade.

6 Thompson (2011, p. 79) entende formas simbólicas como um "amplo espectro de ações e falas, imagens e textos, que são produzidos por sujeitos e reconhecidos por eles e outros como construtos significativos. Falas linguísticas e expressões, sejam elas faladas ou escritas, são cruciais a esse respeito. Mas formas simbólicas podem também ser não linguísticas ou quase-linguísticas em sua natureza (por exemplo, uma imagem visual ou um construto que combina imagens e palavras)".
} 
dominação aqui será entendida nos mesmos termos propostos por Thompson (2011), que a vê

[...] quando relações estabelecidas de poder são "sistematicamente assimétricas", isto é, quando grupos particulares de agentes possuem poder de uma maneira permanente, e em grau significativo, permanecendo inacessivel a outros agentes, ou a grupos de agentes, independentemente da base sobre a qual tal exclusão é levada a efeito (THOMPSON, 2011, p. 80).

Essa dominação se refere, nesse caso, principalmente ao poder exercido pelo governo ditatorial sobre a imprensa, que precisava encontrar estratégias de sobrevivência frente a um Estado cada vez mais autoritário. Dessa forma, Realidade como meio de comunicação de massa produtora de sentidos era um espaço de disseminação de formas simbólicas ideológicas. Embora menos recorrente na primeira fase da revista, o aspecto conservador proposto por Faro (1999) será entendido aqui como produção de sentido necessária para manutenção editorial da revista por meio da sustentação da ideologia dominante, mesmo que internamente a equipe de jornalistas fosse contrária ao golpe e tenha transgredido os valores hegemônicos em diversos outros momentos em sua primeira fase, pois existia uma relação de submissão da imprensa frente à ditadura. Assim, pode-se entender os perfis dos militares como estratégia de legitimação própria da revista junto à ditadura civil-militar, ao mesmo tempo em que, nesses momentos, legitimava o governo ditatorial frente aos leitores.

Para entender a relação ditadura civil-militar/ revista Realidade, utilizaremos as concepções de Thompson (2011) acerca de ideologia. O autor propõe uma formulação própria do conceito, mantendo elementos das "concepções criticas de ideologia", com algumas adaptações, como a exclusão de critérios de negatividade em sua formulação. O autor não acredita que o fato de serem errôneas ou ilusórias sejam caracteristicas fundamentais para compreender as formas simbólicas como ideológicas. Elas até podem aparecer dessa forma, entretanto não necessariamente as são. Por outro lado, a sustentação de relações de dominação é um critério mantido por Thompson (2011) como definidor de ideologia. Portanto, o autor concebe a seguinte formulação do conceito de ideologia:

[...] maneiras como o sentido, mobili-
zado pelas formas simbólicas serve
para estabelecer e sustentar relações
de dominação: estabelecer, querendo
significar que o sentido pode criar ati-
vamente e instituir relações de domi-
nação; sustentar, querendo significar
que o sentido pode servir para manter
e reproduzir relações de dominação
através de um continuo processo de
produção e recepção de formas sim-
bólicas (THOMPSON, 2011, p. 79).

Realidade possuia uma relação complexa com a política e o governo ditatorial, principalmente em sua primeira fase, anterior ao Ato Institucional $n^{\circ} 5$. Isso se deve ao fato de o contexto ser de incertezas sobre os limites até os quais a publicação poderia chegar nas suas pautas e discussões. Efetivamente, o governo passaria a operar com mais ênfase e repressão sobre a imprensa com a instauração do Al-5, de dezembro de 1968, o que coincide com o término da primeira fase de Realidade. Mesmo sem contar com a presença de um censor na redação, o impacto do Ato Institucional é evidente na publicação da Abril, que perdeu muitas das suas caracteristicas fundamentais e passou a trazer pautas e discussões muito mais brandas. Entretanto, a relação de dominação sempre existiu. Primeiramente, de forma implícita. O resultado foi a prática da autocensura, recorrente na imprensa da época. Os veículos não tinham a intenção de se indispor com um governo que já apresentava muitos traços de autoritarismo, o que se agravaria depois, tornando a dominação muito mais explícita.

[Na primeira fase da revista] Não havia uma censura explicita. Havia uma cautela, preocupada com dois niveis. Um, dentro da própria empresa, obviamente defensora do livre mercado. que não concordaria com as veleidades socialistas da equipe. Outro, com o governo: não era o caso de cutucar a onça com vara curta", como se dizia (MARÃO; RIBEIRO, 2010, p. 27).

Apesar de contar com certa liberdade, Realidade, na sua primeira fase, sofreu dois 
casos isolados de censura. O primeiro deles está relacionado à pesquisa "A juventude diante do sexo" publicada na edição 5, de agosto de 1966. A pesquisa continuaria em uma segunda parte na edição seguinte. Mas ela não foi publicada. Em vez disso, o editorial ${ }^{7}$ anunciava a ameaça de apreensão da revista por parte do Juizado de Menores da Guanabara caso a conclusão da pesquisa estivesse presente na edição. A advertência relatada no editorial seria pelo fato de o artigo ser "obsceno e chocante". A postura da revista foi de evitar um confronto mais intenso. Assim, foi anunciada a suspensão temporária da publicação da segunda parte da pesquisa.

O outro caso foi a apreensão da edição número 10, de janeiro de 1967, dedicada exclusivamente a temas relacionados às mulheres. Era uma edição especial temática intitulada "A Mulher Brasileira, Hoje". Mais uma vez, o problema foi com o juizado de Menores. O editorial ${ }^{8}$ da edição seguinte mostra que a apreensão se dava pelo fato de a revista ser considerada obscena e ofensiva à dignidade da mulher. O texto mostrava indignação pelo fato de a decisão de um juiz acarretar a proibição de circulação da revista em todo o País, questionando a liberdade de imprensa no período, que estaria em perigo.

São vários os modos como o sentido pode operar para estabelecer e sustentar relações de dominação. Esses modos de operação da ideologia utilizam diferentes estratégias de construção simbólica. Thompson (2011) elenca cinco modos gerais: legitimação, dissimulação, unificação, fragmentação e reificação. Cada um desses modos utiliza diferentes estratégias de construção simbólica. É evidente que a ideologia pode operar de outros modos e que as estratégias de construção simbólica não são necessariamente ideológicas, pois dependem da circunstância em que foram produzidas.

Partimos do pressuposto de que o perfil de Castelo Branco é um dos casos em que Realidade necessitou atribuir sentido a fim de manter relações de dominação por meio de suas formas simbólicas, adquirindo caráter ideológico. Para auxiliar na análise do perfil, também será utilizado o aporte teórico-metodológico de Motta (2013), que visa

[...] servir como um instrumento interpre-
tativo, uma técnica hermenêutica que
revele processos de representação e de
constituição da realidade historicamente
situados, onde há confrontos com outras
representações possíveis. A perspectiva
pragmática adotada aqui implica ne-
cessariamente levar em consideração
fatores extralinguísticos que interferem
no ato comunicativo (MOTTA, 2013, p. 23).

Assim, além de contar com aspectos linguísticos ao olhar para a narrativa, em busca de compreender o sentido, também deve-se voltar a análise para o contexto. Além de compreender que o resultado presente nas páginas de Realidade, assim como qualquer narrativa jornalística, é fruto de diferentes narradores; nesse caso: o veículo, o repórter - Luiz Fernando Mercadante -, e o próprio perfilado, que, aqui, confunde-se com o contexto político da época, por se tratar do lider do governo ditatorial.

\section{Breve contexto político da publicação}

"Há sob a nossa responsabilidade a população do Brasil, o povo, a ordem. Assim sendo, declaro vaga a Presidência da República", bradou o presidente do Senado, Auro de Moura Andrade, em $1^{\circ}$ de abril de 1964, mesmo com João Goulart ainda em solo brasileiro. Com o golpe, apoiado pelos Estados Unidos em um contexto de Guerra Fria frente a uma suposta ameaça comunista, o cargo de Presidente da República foi ocupado interinamente pelo presidente da Câmara dos Deputados, Ranieri Mazzilli.

No dia 9 de abril de 1964, com o objetivo de punir os principais expoentes do governo anterior, agora considerados subversivos, o Comando Supremo da Revolução baixou o primeiro Ato Institucional (Al-1), cuja redação final foi de Francisco Campos. Além de conceder ao comando revolucionário as prerrogativas de cassar mandatos 
legislativos, suspender direitos politicos pelo prazo de dez anos e deliberar sobre a demissão, a disponibilidade ou a aposentadoria dos que tivessem "atentado contra a segurança do pais", o regime democrático ou a probidade da administração pública, o Al-1 determinava que dentro de dois dias seriam realizadas eleições indiretas para presidente e vice-presidente da República. De acordo com as normas constitucionais, o mandato presidencial se estenderia até o dia 31 de janeiro de 1966, data em que expiraria a vigência do próprio ato. O Al-1 cancelava ainda a cláusula constitucional da inelegibilidade, tornando assim candidatáveis à eleição os oficiais militares da ativa. A adoção desse item permitia então a candidatura de Castelo Branco (KORNIS, 19--?).

Dois dias depois, Castelo Branco foi eleito Presidente da República pelo Congresso, com 361 votos. Juarez Távora obteve três votos e Eurico Gaspar Dutra dois, além de 72 abstenções. Com a promessa de entregar o cargo em 31 de janeiro de 1966, teve seu mandato prorrogado já em 17 de julho de 1964, estendendo-o até 15 de março de 1967, com eleições marcadas para outubro de 1966. As pressões de uma ala militar mais dura por um fechamento maior do regime e o rompimento de líderes civis apoiadores do Golpe com o governo de Castelo Branco levaram à instauração de um segundo Ato Institucional.

Além de extinguir os partidos políticos existentes e estabelecer eleições indiretas para a presidência da República, o novo ato reabriu o processo de cassações de mandatos e suspensão de direitos políticos. Concedeu também amplos poderes ao presidente, como a iniciativa exclusiva das leis sobre matéria financeira e a faculdade de ordenar o recesso do Congresso e legislar por decretos. O ato facilitava a intervenção federal nos estados, assim como a decretação do estado de sítio no país. $\mathrm{Na}$ esfera do Poder Judiciário, o Al-2 ampliou a competência da Justiça Militar, que passou a julgar os civis acusados de crimes contra a segurança nacional, além de aumentar de 11 para 16 o número de juizes do STF (KORNIS, 19--?).

O novo ato deu mais poder para a chamada "linha dura" dentro da ditadura, pois nasceu de uma insatisfação desse grupo com o rumo das eleições para governadores estaduais na Guanabara e em Minas Gerais (FICO, 2019). Apenas duas agremiações partidárias passaram a vigorar no Brasil: a Aliança Renovadora Nacional (Arena), pela situação, e o Movimento Democrático Brasileiro (MDB), como oposição. No início de 1966, a sucessão presidencial já era fortemente debatida e o nome do general Artur da Costa e Silva, líder da chamada "linha dura", despontava como favorito, tendo sua candidatura homologada em maio. Antes disso, Castelo Branco havia decretado o Al-3, estabelecendo eleições indiretas para os governos estaduais e definindo o calendário eleitoral.

Nesse contexto, o ditador Humberto de Alencar Castelo Branco teve o seu perfil publicado na terceira edição de Realidade, de junho de 1966. Em uma matéria de seis páginas, Luiz Fernando Mercadante constrói a imagem do primeiro líder da ditadura civil-miliar do Brasil após o Golpe de 1964, com o título "Êste é o Humberto", e a linha de apoio perguntando: "Afinal como é o homem que se esconde atrás do Presidente?"

\section{Um avô demasiadamente humano \\ - Castelo Branco sob o olhar de \\ Mercadante}

Êste é o Humberto inicia na página 52 da terceira edição de Realidade. A reportagem abre em página dupla com uma foto do ditador sorridente em toda a extensão da página direita. A linha de apoio - "Afinal como é o homem que se esconde atrás do Presidente?" - já demarca uma das intencionalidades do texto: apresentar o lado "humano" do presidente. Desvendar suas caracteristicas de homem comum, fugir da aura de Presidente da República, uma posição superior e distante do público, além de afastar a pecha de autoritário da sua figura.

A primeira sequência criada pelo narrador introduz um personagem discreto: "O homem chegou de mansinho, com muita simplicidade" (MERCADANTE, 1966, p. 52). A cena se passa em uma festa, o "aniversário da parenta", cheia de convidados. Apesar da tentativa de não chamar a atenção para si, logo o presidente acaba tomando 
conta da festa. Ele recusa uísque e evita falar em política e economia, prefere cinema e uma piada:

Após a visita do General De Gaulle ao Brasil, decidi presenteá-lo e, para isso, escolhi um automóvel de fabricação nacional. Enviei-lhe um Volkswagen. Dizem que o General gostou muito, pelo menos até a hora em que foi experimentá-lo e, apesar dos muitos esforços, não conseguiu entrar no veículo, extremamente pequeno para o seu avantajado tamanho. De Gaulle, então, um tanto aborrecido, apressou-se em me mandar um bonito cachecol como retribuição (MERCADANTE, 1966, p. 52).

Difícil afirmar se a piada realmente foi contada por Castelo Branco ou se Mercadante aproveitou a narrativa e sua liberdade criativa para brincar com a forma física do lider do governo ditatorial, colocando a piada em sua fala, deixando-a menos agressiva. Fato é que a situação auxilia na construção de um personagem empático capaz de rir de si mesmo.

O personagem é uma pessoa comum ocupante de um alto cargo, em posição de poder frente aos demais cidadãos. Na saída da festa, gera espanto no casal com quem divide o elevador: "Puxa vida! O que é que o Castelo Branco anda fazendo aqui a esta hora?" (MERCADANTE, 1966, p. 52). Esses personagens secundários configuram uma estratégia de apoio ao ponto de vista do narrador, fortalecendo sua construção simbólica, nessa sequência, de um sujeito como qualquer outro brasileiro, que evita alardes e a fama pela posição que ocupa, colocando-se em igualdade com as demais pessoas. Esse Castelo Branco low profile é mais uma vez sustentado pelas características do Mercedes que o leva até o Palácio Laranjeiras: "prêto, de chapa particular, sem batedores, nem sirenas - despercebido, como gosta de andar" (MERCADANTE, 1966, p. 52). Mas esse sujeito simples contrasta em alguns aspectos com a figura de Presidente. O carro o leva até o Palácio, apresentado como seu mundo oficial, e só então o personagem é totalmente revelado após toda essa cena introdutória: Marechal Humberto de Alencar Castelo Branco.

Dentro dessa mesma sequência inicial, mas em outra cena, Mercadante aprofunda a humanização do relato ao narrar um drama pessoal de Castelo Branco: a morte de sua esposa, Argentina, oito meses antes de sua posse. A narrativa conta que, de mês em mês, ele vai ao cemitério levar flores para a esposa. A carga dramática trazida pela solidão expressa em sua fala introduz novos elementos à construção do personagem: "- Desde que perdi minha espôsa me sinto um homem muito só" (MERCADANTE, 1966, p. 52). A partir disso, uma série de adjetivações confere outros traços ao personagem de 65 anos: ar vagamente triste; homem baixinho; feioso e tímido. Por outro lado, é "capaz de exercer a Presidência da República com a segurança de quem recebe, apenas, uma promoção a mais na carreira" (MERCADANTE, 1966, p. 52). Ressaltando que, para o personagem, ocupar tal posição nada interfere na sua "essência" como ser humano, sem alterar as características que possuía antes disso. As idiossincrasias, as complexidades da personalidade humana e os detalhes selecionados produtores de efeito de real seguem nessa introdução do personagem, como uma figura equilibrada, capaz de dosar entre as oposições de personalidade necessárias em sua vida, mesclando com a exposição de características físicas:

Sabe alternar a carranca com um ligei-
ro sorriso, ou assumir o ar neutro das
pessoas formais. Tem os polegares
curtos, marca das pessoas teimosas, ea
expressão determinada de quem sabe o
que está fazendo. Seus ternos, escuros
e bem talhados, lhe assentam melhor
que a farda aposentada. A faixa presi-
dencial teve que ser apertada para lhe
servir bem. Seus óculos estão sempre
onde êle os procura: no bôlso interior
do paletó. São bifocais, usados para ver
de muito perto ou de muito longe. Os
cabelos estão embranquecendo. Sete
vêzes avô, êle vai se transformando num
velhinho simpático, que dosa a severi-
dade com um pouco de bom humor e
sabe que não é preciso ser chato para
ser austero (MERCADANTE, 1966, p. 52).

O narrador faz uso da racionalização (THOMPSON, 2011), isto é, as caracteristicas do personagem são encadeadas na primeira sequência, fundindo os traços mais simples de uma vida humana com características esperadas 
de um presidente, resultando em um pleno equilibrio, criando uma figura digna de apoio. A construção simbólica se dá também por meio da escolha das imagens que dialogam com o texto e compõem as páginas da revista. Nesse caso, a fotografia em página inteira que abre a matéria se destaca na produção de sentido em consonância com a sequência em questão: Humberto de Alencar Castelo Branco com um sorriso espontâneo (Figura 1).

Figura 1 - Humberto de Alencar Castelo Branco com sorriso espontâneo

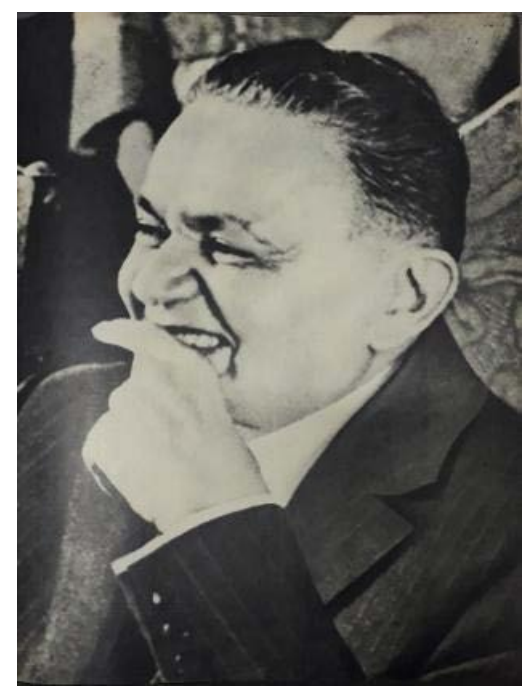

Fonte: Realidade. São Paulo: Ed. Abril, ano I, n. 3, p. 53, junho de 1966.

A segunda sequência passa a focar na rotina de Castelo Branco como Presidente do Brasil. Mostra como ele se divide entre Rio de Janeiro e Brasilia para governar o país, trazendo detalhes dos seus hábitos, como a escolha do mesmo assento nos voos: "do centro, à direita, junto à janela" (MERCADANTE, 1966, p. 54). O personagem também aproveita os voos para trabalhar, cumprindo obrigações mais urgentes ali mesmo. Mas se estiver cansado, ele "tira uma soneca. De pijama e tudo" (MERCADANTE, 1966. p. 54). Mais uma vez, fortalecendo o efeito de casualidade na personalidade do personagem. Em uma conversa com Carlos Lacerda, mostra não se importar com as críticas, que não lhe tiram o sono, pois come e bebe muito bem quando as recebe, principalmente as vindas do jornalista.

A narrativa segue os passos de um dia na rotina do ditador ao chegar em Brasília: toma banho frio de manhã; faz a barba sozinho; o café da manhã - "duas laranjas-lima, indispensáveis, uma fatia de mamão sem açúcar, café com leite, pão com manteiga - mais casca que miolo - e uma fatia de queijo" (MERCADANTE, 1966, p. 54). Às sete horas já está com tudo pronto e trabalhando. Os detalhes do ambiente de trabalho no Palácio da Alvorada também auxiliam na produção de sentido: escrivaninha preta, cheia de livros e papéis e uma imagem de Nossa Senhora. Essa composição do escritório suscita a construção de formas simbólicas no imaginário do leitor, expressando diferentes valores: seriedade (escrivaninha preta); muito trabalho (mesa coberta de papéis); erudição (coberta de livros); religiosidade (imagem de Nossa Senhora). No ambiente que exige meditação para a resolução de problemas, Mercadante também mostra que, quando de bom o humor, o personagem cantarola enquanto trabalha: "Olé mulé rendera. Olé mulé renda" (MERCADANTE, 1966, p. 54).

Uma hora depois, parte para o Palácio do Planalto. Entretanto, o narrador mostra que Castelo Branco antes passa, às vezes, na casa de sua filha para dar bom dia aos netos, evidenciando uma figura amorosa, preocupada e apegada à família. O texto frequentemente faz alusões às nuances entre a vida pública e a vida privada do ocupante do cargo de presidente, ressaltando oposições e entrelaçamentos. A chegada no Palácio do Planalto é quase uma exaltação ao resgate de antigos valores de patriotismo e respeito à República, que estavam perdidos ou deturpados nos tempos recentes. O narrador mostra que Castelo não abre mão da solenidade em sua chegada e saída do local, com toques de clarim, continências e hasteamento da bandeira presidencial, diferente dos ex-presidentes que optavam por entrar e sair pelos fundos. "Fêz questão de restaurar a esquecida cerimônia que deve cercar a chegada e a saida do Presidente, como que para reimprimir ao cargo um tom de dignidade quase esquecido" (MERCADANTE, 1966, p. 54). 
Em seguida, o texto mostra o dia de trabalho no Planalto e como Castelo Branco atende às pessoas: "Ouve mais do que fala; pergunta mais do que responde; oferece um cafezinho enquanto toma um gole de água gelada, e vai ficando de pé, assim que o assunto está para se esgotar" (MERCADANTE, 1966, p. 54). Pode-se notar que Mercadante apresenta um presidente atencioso, cordial, aberto a ouvir as pessoas, e que não gosta de perder tempo no trabalho. Depois, lê o resumo dos jornais e o boletim do Serviço Nacional de Informações, antes de voltar para o Palácio da Alvorada na hora do almoço. Assim como no café da manhã, detalhes como o cardápio são descritos. Destaca-se, aqui, mais uma vez o distanciamento do personagem às bebidas alcoólicas e a sua sobriedade, tendo a água como bebida oficial, apesar de os convidados terem direito a um copo de cerveja e, em ocasiões especiais, a um vinho, mas sempre de produção nacional. Ainda no seu intervalo, o texto mostra que Castelo Branco gosta de caminhadas e de meia hora de repouso, além de destacar como sempre veste roupas escuras, "seu guarda-roupas vai do cinza forte ao prêto. Escuras, também, as gravatas" (MERCADANTE, 1966, p. 54).

Na volta ao Planalto, destaca-se como o texto apresenta o forte aparato de segurança altamente qualificado para a defesa do ditador em Brasília, embora no Rio ele consiga driblar esse esquema para andar solitário. Isso serve de gancho para ressaltar a importância da figura de Castelo Branco, o homem "mais poderoso da República"(MERCADANTE, 1966, p.57). Em seguida, são apresentadas as atribuições e as grandes responsabilidades do cargo de Presidente. Assim, os subsídios de 2.455 .000 cruzeiros acrescidos de um milhão de verbas de representação mensais do cargo de presidente são eufemizados (THOMPSON, 2011), colocando-os em perspectiva com o de um diretor de uma grande empresa, o que torna o valor "pouco". O tom é quase de esforço e sacrifício em prol do Brasil, sujeitando-se a uma carga exagerada de trabalho, uma jornada interminável - "lhe toma os dias e até as noites, que não the poupa sequer os fins de semana e the exige permanente atenção" (MERCADANTE, 1966, p. 55). Está submetido a grandes responsabilidades sem o devido reconhecimento financeiro. $O$ trabalho é apresentado de tal forma que seria praticamente imensurável em valores, impossivel haver quantia que faça jus a tamanhas atribuições. Em seguida, sua imagem será construida a fim de se mostrar digno e preparado para assumir tais responsabilidades.

O texto ainda narra o prestígio de Castelo Branco perante a sociedade com sucessivos convites para homenagens de diferentes setores, e como faz questão de aceitar todos eles, ressaltando uma proximidade entre a figura presidencial e a população brasileira. "- O Presidente gosta de atender convites, de visitar lugares, de conhecer pessoas. Enfim, gosta de tomar contato com as diversas regiões e conhecer-lhes de perto os problemas - afirma o chefe do Gabinete Civil, o escritor baiano Luis Viana Filho" (MERCADANTE, 1966, p. 55). A fala do chefe do Gabinete Civil também dissimula (THOMPSON, 2011) a narrativa. Qualidades que qualquer governante deveria ter, que são básicas, como a preocupação em conhecer cada região do país, são apresentadas de forma excepcional, como um diferencial de Castelo Branco, construindo uma figura extremamente preocupada com o Brasil e com o seu povo, quando, na verdade, isso é o mínimo esperado de alguém que ocupa tal cargo. A narrativa segue exaltando o grande volume de trabalho que chega via telex e a agitação do dia, até o fim do longo expediente, às 2oh. "E o telex continua matracando" (MERCADANTE, 1966, p. 55).

A página dupla possui uma sequência narrativa fotográfica à parte para a construção do avô Castelo Branco (Figura 2). Com o título: "Um menino vive na noite do Presidente", uma pequena história com forte carga simbólica é contada em uma série de fotos. Como visto, o personagem resgatou o prestígio e as tradições solenes para a chegada do presidente ao Planalto, seguindo à risca a formalidade da cerimônia. Entretanto, uma única coisa pode quebrar a tradição: a presença de João Paulo, seu neto. Como mostra a legenda, dessa forma, o protocolo suporta docemente o 
arranhão. A sequência traz o presidente seguindo os ritos tradicionais de entrada no Palácio do Planalto, depois uma criança corre em direção a ele, ambos se abraçam e, por fim, seguem a caminhada de mãos dadas. A narrativa constrói um personagem humano e amável, rígido com as tradições e com seus valores, mas capaz de fazer concessões em sua postura firme para demonstrar afeto e carinho pela familia.

Figura 2 - Sequência fotográfica "Um menino vive na noite do Presidente"

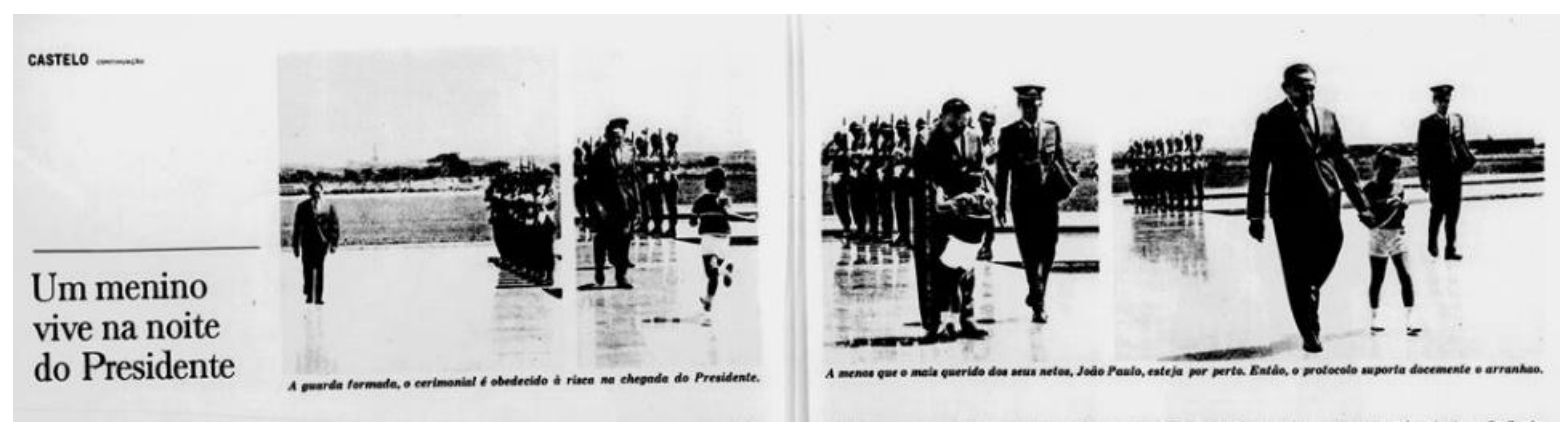

Fonte: Realidade. São Paulo: Ed. Abril, ano I, n. 03, p. 54-55, junho de 1966.

A sequência posterior a da apresentação da rotina presidencial se relaciona com a sequência da foto, retornando à vida privada de Castelo Branco. O texto diz que a única vez no dia em que ele esquece a República é quando pergunta ao seu assessor e genro sobre a febre do seu neto João Paulo, o mesmo das fotografias. "João Paulo é o neto predileto, um garôto de seis anos capaz de transformá-lo, em um minuto, no mais terno dos avós" (MERCADANTE, 1966, p. 55). Esse processo de humanização da figura de Castelo Branco segue, mostrando constantes preocupações com a familia mesmo em momentos importantes de sua rotina, revelando uma pessoa carinhosa por trás da rigidez e da ocupação.

Nessa narrativa da vida privada de Castelo Branco, o consumo de cultura erudita é constantemente ressaltado. Ao fim do dia, ouve Bach em sua vitrola e lê Érico Veríssimo. Embora tenha que revezar o prazer com alguns afazeres do cargo, mesmo em momentos de descanso e lazer. O narrador aproveita o fim do dia e o momento de dormir para criar um link com uma nova sequência: o passado do ditador. O retorno à infância é marca constante nos perfis escritos por Mercadante, que representa o presente como uma continuação lógica desse passado:
Nessas noites de Brasilia, antes que o sono chegue, ele costuma "retornar às suas origens" lembrando passagens da infância, dos dias despreocupados em que corria descalço pelo engenho do avô, onde os empregados gostavam de lhe dar bom dia e o chamavam carinhosamente de "menino Humberto".

Menino Humberto nunca teve medo de escuro. Levantava bem cedo, caneca na mão, e se despachava para o curral. Quando os vaqueiros chegavam para a ordenha já encontravam o menino sentadinho ao lado da vaca. Uma vez apostou com um dos irmãos:

- Vamos ver quem consegue encher uma caneca primeiro:

Ganhou fácil: passara uma semana treinando em segredo (MERCADANTE, 1966, p. 55).

A narrativização (THOMPSON, 2011) da história do "menino Humberto" cria um personagem com aspectos de coragem, querido pelos empregados e com vocação para o trabalho. Como qualquer criança, o texto mostra algumas molecagens, como algumas brincadeiras com os animais. Mas o narrador prossegue com um saudosismo quase poético dos tempos de criança do personagem:

Por trás disso tudo havia menino Humberto, com seus olhos brilhando e o mesmo ar encabulado que carrega até hoje. Em tôrno da simplicidade da casa grande, menino Humberto 
cresceu brincando de pé no chão. Dali escapava para banhos de açude e intermináveis correrias pelos canaviais (MERCADANTE, 1966, p. 55).

A narrativa passa a aproximar Castelo Branco da carreira militar, mostrando como brincava de soldado na infância e que sonhava em ser capitão. Inclusive o subtítulo da página em destaque diz: "Êle queria o máximo: chegar a capitão", abaixo de uma foto de Castelo Branco mais jovem com sua esposa, Argentina, e a legenda: "Sua mulher não o viu como presidente" (Figura 3).

Figura 3 - Castelo Branco ao lado de Argentina

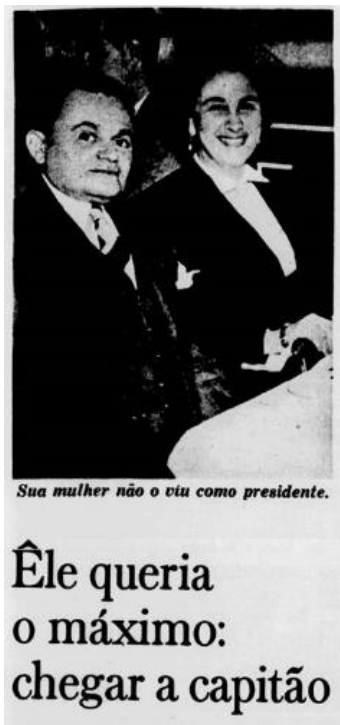

Fonte: Realidade. São Paulo: Ed. Abril, ano I, n. 03, p. 56, junho de 1966.

Em seguida, o narrador apresenta as origens da familia de Castelo Branco, buscando uma tradição militar que remonta ao século XVII, com um Capitão de Infantaria do Exército Português, de quem ele descende em oitava geração. Depois, a sua trajetória durante a formação escolar e militar passa a ser o foco e a exaltação de qualidades do passado continua:

A imagem que deixou como estudante, desde o primário até as escolas militares, foi a de um aluno muito aplicado, correto e dedicado aos estudos. Tinha boa letra, encapava todos os livros, era taco em línguas, gostava de História e Geografia, enfrentava bem a Matemática e era sempre um dos primeiros da turma (MERCADANTE, 1966, p. 57).

A imagem de intelectual é reforçada por sua participação na Sociedade Literária da Escola em Porto Alegre, onde se tornou orador oficial, declamando Castro Alves e José de Alencar, com quem é destacado um vínculo familiar. Nessa cadeia de fatos do passado de Castelo Branco, a narrativa caminha para uma sequência de legitimação (THOMPSON, 2011), que justifica o poder exercido no momento de publicação do texto, como se a dedicação aos estudos, o bom desempenho escolar, a coragem, a determinação para qualquer tipo de trabalho e para vencer disputas representassem o alicerce necessário e os valores desejáveis à figura de um presidente. Esse raciocínio avança no decorrer da narrativa, abordando sua juventude e o grande êxito na carreira militar:

\begin{abstract}
Quarenta e seis anos de vida ativa no Exército constituem seu passado de soldado, um soldado que se destacou alcançando todas as promoções por merecimento e que, durante toda a sua vida militar, alternou comandos.

De toda essa folha de serviços, pontilhada de condecorações e elogios, o que Castelo Branco recorda com mais orgulho é a sua atuação nos campos da Itália, onde exerceu a chefia da $3^{\mathrm{a}}$ seção do Posto de Comando Avançado da Força Expedicionária Brasileira. Era, então, um jovem tenente-coronel disposto a colocar em ação seus conhecimentos táticos e habilidades de estrategista (MERCADANTE, 1966, p. 57).
\end{abstract}

A sólida carreira militar de Castelo Branco é mais um dos elementos que compõem o raciocínio desenvolvido para justificar o lugar de poder ocupado pelo militar. Dessa forma, a racionalização (THOMPSON, 2011) volta como estratégia de construção simbólica da figura do personagem perfilado. Sua atuação na FEB, onde ganhou o apelido de Gafanhoto, é destacada com episódios que remetem a valores como dedicação, tranquilidade, homem respeitado até mesmo pelos estadunidenses e estrategista; apreciador de música clássica, que planejou ataques ao som de ópera em sua vitrola. 
Depois, a narrativa caminha mais fortemente para a atualidade e a justificação de sua posição. Mercadante coloca Castelo Branco no chamado Grupo dos Cinco, um grupo de militares vinculados à Escola Superior de Guerra, importante no Golpe de 1964. Além dele, o grupo é composto pelos generais Cordeiro de Farias, Juraci Magalhães, Golberi do Couto e Silva e Jurandir de Bizarria Mamede.

Luiz Fernando Mercadante destaca a função de cada um dos membros do grupo dos cinco e encontra um espaço para trazer um pouco de acidez e crítica ao texto ao falar de Golberi, diretor do SNI: "Dizem as más línguas que o SNI não funciona às segundas-feiras, dia em que não circula a maioria dos jornais" (MERCADANTE, 1966, p. 57). O texto ressalta a importância dos cinco generais nos rumos do Brasil e mostra como Castelo foi quem assumiu o principal posto na condução do país:

- O Castelo - diziam eles - daria um ótimo
Presidente.
E quando os governadores, os políticos
e os militares, integrados na Revolução,
procuravam um nome que concilias-
se todas as tendências para ocupar a
Presidência da República, Cordeiro,
Juraci, Golberi e Mamede trabalharam
o nome do seu companheiro, daquele
general que na chefia do Estado-Maior
do Exército foi peça importante em toda
a conspiração e um dos chefes mais si-
lenciosos do movimento. Assim, aquele
general deixou o exército. Passou para
a reserva, no posto de marechal e assu-
miu o primeiro posto civil de sua vida: a
Presidência (MERCADANTE, 1966, p. 58)

A aceitação unânime dessa parte da cúpula golpista evidencia a construção do caráter excepcional de Castelo Branco em relação aos demais, quase como uma sintese conciliatória das diferentes vertentes de pensamentos entre os mentores do golpe civil-militar, afastando a construção simbólica dos ares antidemocráticos do governo ditatorial, apresentando sua figura como uma escolha coerente e justificada.

Ao falar da posse de Castelo Branco, o texto começa a afastar um pouco sua imagem da vida militar e o torna mais civil, decepcionando jornalistas russos do Pravda que acompanhavam o evento:
Os russos esperavam-no fardado, dependurado em quilos de condecorações e arrastando uma espada pelo chão, no melhor modêlo latino-americano. O homem sereno e determinado que entrou em passos seguros, vestindo o mais paisano dos ternos de passeio, contrariava a previsão.

- Que pena - comentou o representante do Pravda - o homem está até de colête (MERCADANTE, 1966, p. 58).

A narrativa exalta seu discurso de posse e conta as vinte e duas interrupções para aplausos. "Dificilmente outro militar conseguiria dar um tom tão civil à oração de posse" (MERCADANTE, 1966, p. 58). O narrador ainda traz uma passagem em que entrevista o sogro de Castelo Branco. Ele também exalta as qualidades do então líder da ditadura e o fato de ainda manterem uma relação próxima, mesmo depois da morte de Argentina. Além disso, Mercadante apresenta brevemente os irmãos, as irmãs, o filho e a filha de Castelo Branco e seus netos, destacando, mais uma vez, João Paulo que "apesar da pouca idade, já fala em ser soldado" (MERCADANTE, 1966, p. 58). A foto da última página (Figura 4) traz o ditador com o dedo em riste e o destaque: "Êle não fuma, não bebe, só joga xadrez".

Figura 4 - Humberto de Alencar Castelo Branco com o dedo em riste

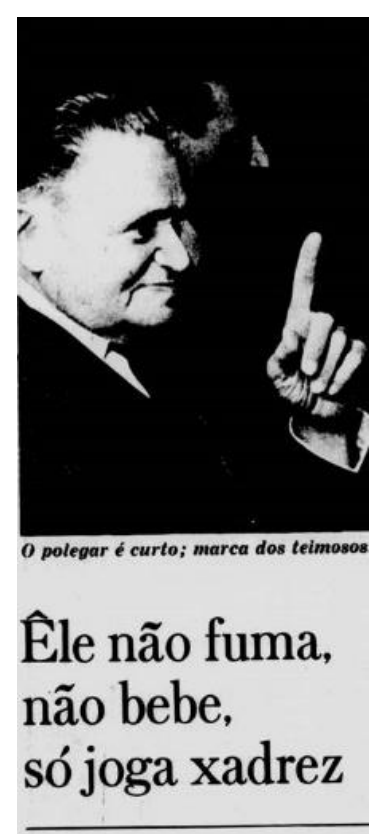

Fonte: Realidade. São Paulo: Ed. Abril, ano I, n. 3, p. 58 , junho de 1966. 
Trazer elementos que possam parecer carismáticos, características humanizadoras, geradoras de empatia, a presença de hábitos cotidianos, a simplicidade, ou seja, representar a vida do personagem como a de uma pessoa comum, são formas de apresentar o perfilado que compõem estratégias narrativas recorrentes nesse gênero. No caso de Castelo Branco, isso contribui na produção de sentido positivo perante a sociedade, narrado como um homem sensivel, muito apegado à familia e com gostos sofisticados na sequência final do texto:

Em familia o Presidente é um homem simples e carinhoso, capaz de passar horas conversando com os parentes e que gosta de receber notícias até de primos distantes que não vê há tempos. Não fuma, não bebe. Mas é páreo numa partida de xadrez. Em futebol, só torce para o Brasil e tem uma simpatia por Pelé Mas não é seu forte. Gosta mesmo é de balé, clássico e moderno, ou de um bom teatro. É católico praticante e não tem superstições (MERCADANTE, 1966, p. 58).

Por fim, Mercadante destaca a dificuldade de Castelo Branco em levar uma vida de cidadão comum, nas atividades cotidianas mais simples, como marcar um médico ou comprar entradas para o teatro, pois ninguém acredita que realmente é ele quem está realizando tais tarefas. A narrativa contribui para a edificação da figura de Castelo Branco e para a construção de uma imagem mais moderada e menos autoritária que, inclusive, passaria para a posteridade como uma das memórias dominantes sobre a época, entretanto, de acordo com Fico (2019), essa hipótese não se sustenta:

Para muitos analistas, Castelo Branco deixou as marcas de moderado e legalista mas, de fato, não foi uma coisa nem outra. Além de ter conspirado contra o presidente a que servia, assumiu o governo com poderes discricionários. Foi responsável por iniciativas muito duras, como a Lei de Segurança Nacional, cuja passagem sobre a noção de "guerra interna" ele ajudou a redigir. Determinou a invasão $e$ o recesso do Congresso Nacional quando o parlamento não aceitou a cassação de seis deputados federais em 1966. Decretou uma lei de imprensa restritiva e, sobretudo, fracassou em não conter a linha dura (FICO, 2019, p. 57).

Assim, percebe-se o poder contido em uma narrativa, no encadeamento de ideias e nas estratégias de construção simbólica, pelas quais a ideologia dominante opera e produz sentidos nos leitores, capaz de mascarar a realidade e recriar histórias enviesadas e com um propósito definido.

\section{Considerações finais}

A construção simbólica da figura do primeiro líder do governo ditatorial legitima seu status de poder por meio de narrativas do passado e o representam, no presente, como portador de bons hábitos, sem vícios, religioso, preocupado com a familia e de gostos refinados. Essas estratégias utilizadas por Realidade também servem como artifício de autolegitimação frente à ditadura, como uma espécie de álibi para a abordagem de assuntos mais delicados, considerados de maior relevância para a equipe de jornalistas, geralmente no plano dos costumes.

As informações sobre o general não são necessariamente errôneas e ilusórias (THOMPSON, 2011). Cada uma das informações trazidas por Mercadante pode, sim, ter um referencial na realidade. O importante aqui é notar como o repórter construiu as sequências que dão lógica à narrativa e constroem a imagem apresentada de Castelo Branco; com que fins ideológicos isso foi produzido; e que implicações isso tinha no contexto de produção, pois cada linha de um texto jornalístico é fruto de escolhas em um universo infinito de possibilidades narrativas, o que evidencia seu caráter político.

Ao analisar publicações seriadas, deve-se levar em conta que elas também fazem parte de um contexto próprio, não só do contexto geral políticoeconômico-social do "mundo lá fora", mas também de um contexto interno, com certa correlação entre uma edição e outra, com elementos referenciais que dizem respeito a própria história da revista, seja em sequência de pautas, jogos de palavras etc. A carta do leitor é uma dessas pontes com edições passadas que acontece no momento subsequente, o que não impede que outras pontes possam ser ligadas entre edições um tanto mais espaçadas temporalmente. A revista aproveita esse mecanismo para se afirmar como não opositora ao governo ditatorial e desviar qualquer suspeita 
em relação a isso, ainda mais por se tratar de uma publicação nacional de grande tiragem e de uma grande editora. A edição seguinte, número 4, seleciona, entre outras, a seguinte carta:

\section{Nenhum perigo}

Sr. Diretor: REALIDADE veio provar que a Editôra Abril não constitui nenhum perigo à soberania da Pátria, como querem alguns órgãos de nossa imprensa. Está se mostrando, isto sim, uma excelente revista de formação, que muito irá contribuir para o desenvolvimento intelectual do Brasil.

Lewys S. Andrade - estudante Lavras - MG (REALIDADE, julho de 1966, p. 7)

A revista responde: "REALIDADE só é perigosa para os que temem uma imprensa moderna e séria". Apesar de não fazer referência direta ao perfil da edição anterior, a mensagem selecionada para compor a seção de cartas reforça a matéria, afastando a imagem de oposição ao governo ou de possuir uma redação comunista, ou seja, não configura "nenhum perigo".

\section{Referências}

FARO, J.S. Revista Realidade, 1966-1968. Tempo da reportagem na imprensa brasileira. Porto Alegre: Ulbra/ AGE, 1999 .

FICO, Carlos. História do Brasil Contemporâneo. São Paulo: Contexto, 2019.

KORNIS, Mônica. Castelo Branco, Humberto. Verbete. Centro de Pesquisa e Documentação de História Contemporânea do Brasil, Fundação Getúlio Vargas. Disponivel em: http://www.fgv.br/cpdoc/acervo/ dicionarios/verbete-biografico/humberto-de-alencar-castelo-branco.

LEISTER FILHO, Adalberto. Entre o sonho e a realidade: pioneirismo, ascensão e decadência da revista realidade (1966-1976). Dissertação. (Mestrado) - USP, São Paulo, 2003.

MARÃO, José Carlos; RIBEIRO, José Hamilton. Realidade re-vista. Santos: Realejo Edições, 2010.

MERCADANTE, Luiz Fernando. Êste é o Humberto. Realidade, São Paulo/Ed. Abril, ano I, n. 03, jun. 1966

MOTTA, Luiz Gonzaga. Análise Crítica da Narrativa. Brasilia: Editora Universidade de Brasilia, 2013

REALIDADE. São Paulo: Ed. Abril, ano I, n. 04, julho 1966.

REALIDADE. São Paulo: Ed. Abril, ano I, n. 06, setembro 1966.
REALIDADE. São Paulo: Ed. Abril, ano II, n. 11, fevereiro 1967.

SEVERIANO, Mylton. Realidade - história da revista que virou lenda. Florianópolis: Insular, 2013.

THOMPSON, John. Ideologia. Ideologia e cultura moderna: teoria social crítica na era dos meios de comunicação de massa. Petrópolis: Vozes, 2011. p. 43-99.

VILAS BOAS, Sergio. Perfis: e como escrevê-los. São Paulo: Summus, 2003.

\section{Jonas Migotto Filho}

Mestrando em História pela Universidade Federal de Santa Maria (UFSM, Santa Maria, RS, Brasil).

\section{Endereço para correspondência}

Jonas Migotto Filho

Universidade Federal de Santa Maria. Av. Roraima, 1000, Cidade Universitária, Prédio 26, sala 1105, Camobi, 97105-900, Santa Maria, RS, Brasil. 